\title{
Confronting the Past Abuses: Indonesia and Southeast Asia
}

\author{
Priyambudi Sulistiyanto \\ College of Humanities, Arts and Social Sciences Flinders University - Adelaide, Australia \\ Email: priyambudi.sulistiyanto@flinders.edu.au
}

\begin{abstract}
This article examines the politics of reconciliation in Indonesia and Southeast Asia. It focuses in particular on the case of Talangsari killings in Indonesia and makes a regional comparison with Thailand, Cambodia, the Philippines and Myanmar. The Indonesian experience illustrates some of the complex issues that arise when attempts are made to dealing with past abuses, especially in the context of the constraints and possibilities faced by new democracies. In a comparative perspective what is being experienced in Indonesia is not new in the sense that, as argued by scholars elsewhere, new democracies also have to face this kind of situation. This article argues that dealing with the past human rights abuses brings about real power struggles among the contending actors and power holders and it reflects the power structures within and outside the country. It is suggested that there is no "universal" model for dealing with past human rights abuses but some form of accountability that brings together the elements of prosecution, reconciliation and forgiveness could be considered.
\end{abstract}

Keywords: Talangsari killing, politics of reconciliation, human rights

\section{A. Introduction}

The public pressure to reinvestigate the Talangsari killings in post-Suharto Indonesia was a show case of the changing of balance of power during the Habibie and the Wahid presidencies (1998-2001) which led to pressures for the governments to deal with the Talangsari case through legal means and/or trials. However, the public pressure was not as great and this was due partly to the fact that there was little attention given to the case by the media and politicians from the Islamic political parties in the Parliament. There were a small number of human rights organizations like the Commission for Disappereances and Victims of Violence (Komisi untuk Orang Hilang dan Korban Kekerasan, Kontras) and solidarity groups who brought the case to the attention of the public. Some representatives of the victims signed islah (peace) agreements with retired General Hendropriyono (until September 2004, he was the head of the powerful Bureau of National Intelligence, Badan Intelijen Nasional, BIA) at the end of 1998. 
This created a division among the victims which later on made the efforts to find a mechanism for deal with the Talangsari case more difficult.

The Talangsari killings occurred on 7 February 1986, in Talangsari village in Lampung province, Sumatera island. Prior to that day, the local government and military officers had been suspiciously monitoring the activities of a Talangsaribased Islamic group led by a charismatic leader known as Warsidi. ${ }^{1}$ This led to the arrest of some members of the group. In response, Warsidi's followers hijacked a car and attacked a police office nearby areas, making the authorities even more determined to crack down on this group. On the way to Talangsari village, the military officers clashed with Warsidi himself and his followers, causing the death of a number of people on both sides. The government responded by deploying military troops (led by then Colonel Hendropriyono) to arrest Warsidi and his followers. However, the situation in the field got out of control, more people were killed, injured and houses were set on fire during the clash. Accounts about the cause of the killings and the number of people who were killed or disappeared remain controversial: some put the death toll in the 30 s while others put it at over 200.2 The killings were followed by the arrest (and later trials) of the followers of Warsidi. The killings also brought condemnation of the Suharto government, especially for using the military to respond to civilians who used traditional weapons for self-defense purposes only. The person that remained the focus of attention was Hendropriyono.

The Talangsari killings occurred in a political climate in which the Islamic community felt traumatised and victimised as a result of the arrests and trials of those who were involved in the case of Tanjung Priok killings (1984). ${ }^{3}$ Itappeared that some of those who were killed in Talangsari village had left Jakarta and other places in Java, looking for refuge in this village. In a sense, as suggested in various accounts, these people looked for refuge (known as hijrah in Arabic) hoping to

\footnotetext{
${ }^{1}$ For further discussion on the causes and consequences of the Talangsari killings, see Al Chaidar, Lampung Bersimbah Darah (Jakarta: Madani Press, 2000); Widjiono Wasis, Geger Talangsari (Jakarta: Balai Pustaka, 2001); and Abdul Syukur, Gerakan Usroh Di Indonesia, Peristiwa Lampung 1989 (Yogyakarta: Ombak, 2003).

${ }^{2}$ Al Chaidar, pp 172-173 and Widjiono, pp 145-146

${ }^{3}$ For the Tanjung Priok killings, see Priyambudi Sulistiyanto, "Politics of Justice and Reconciliation in post Suharto Indonesia”, Journal of Contemporary Asia, 37, 1, 2007, pp. 73-94.
} 
establish a small community where they could practice Islamic teachings freely without government intervention. ${ }^{4}$ It must be stated here that there has been a long tradition of inter-island migration, especially from Java to Lampung. The majority of people who lived in Talangsari village and the nearby areas were ethnic Javanese. Furthermore, the killings occurred in a rural area in where many people working as peasants, village traders, village bureaucrats and also coffee plantation laborers. The combination of these various elements mentioned above also shaped the course of the events leading up to the killings.

As mentioned earlier, public pressure to reinvestigate the human rights violations that happened during the New Order period increased after the fall of Suharto in May 1998, with the Talangsari killings being one case that received attention. As early as the middle of June 1998 the Committee for Moslem Solidarity (Komite Solidaritas Muslim, KSM) visited the National Commission on Human Rights, urging the investigation of the Talangsari killings and the Tanjung Priok killings and also demanding the release of the political prisoners who were implicated in these cases. ${ }^{5}$ At the same time, Kontras also sent its members to Talangsari village in Lampung province, aiming to get first-hand information about the case. ${ }^{6}$ As a result, Kontras came out with a list of persons who were killed and who disappeared. At the local level, there were organizations such at the Legal Aid Foundation-Lampung Branch (Lembaga Bantuan HukumLampung) and the Solidarity Committee of Lampung Students (Komite Solidaritas Mahasiswa Lampung, Smalam) who actively gathered data and information about the case especially given the focus on the possibility of bring the case to trial. In September 1998, other solidarity organisations coming from the areas surrounding Jakarta, the Tangerang-based Solidarity for Islamic Society (Solidaritas Masyrakart Islam Tangerang) and also the Bekasi-based Communication Forum for Young Muslim (Forum Komunikasi Generasi Muda Islam Bekasi) also visited the headquarters of the Indonesian Armed Forces and the Parliament urging the government to address past human rights abuses including the Talangsari case. ${ }^{7}$

${ }^{4}$ Al Chaidar, p, 142 and Widjiono, p, 29.

5 The leader of the Committee is Rachmat Basuki. "Komnas Diminta Usut Kasus Tanjungpriok and Lampung", Kompas, 18 June 1998.

6 “Bawa Soeharto ke Meja Hijau”, Merdeka, 2 September 1998.

7 “Usut Tuntas Kasus Tanjungpriok, Lampung, dan Aceh”, Kompas, 2 September 1998.

JURNAL THEOLOGIA — Volume 32, No. 1, Juni 2021 
At this stage, the public pressure mentioned above appeared as a direct reaction to the early initiatives carried out by Hendropriyono together with a number of former political prisoners, to establish an islah agreement. Some of these initiatives are as follows. ${ }^{8}$ Some time around June 1998, there were a small number of former political prisoners who approached Hendropriyono (then Minister of Transmigration in the Habibie government), asking him to help with the release of those who were still imprisoned in the notorious Nusakambangan prison in Central Java. ${ }^{9}$ Hendropriyono reacted positively to the request and he wrote an official letter dated on 21 August 1998 asking President Habibie to speed up the release of other political prisoners from of the Talangsari case. He also lobbied the Attorney General AM Ghalib, the Minister of Justice, Muladi, the Minister of Defence, General Wiranto and the ChiefJustice, Sarwata, for assistance. A month later, in September 1998, the Attorney General wrote an official letter to Habibie advising him to approve the request made by Hendropriyono. In October 1998, the State Secretary Akbar Tanjung wrote letters to three ministers (the Coordinating Minister for Political Affairs, Faisal Tanjung, the Minister of Defence, General Wiranto and the Minister of Justice, Muladi) explaining the instructions given by the President to assist with the rehabilitation process for the remaining prisoners of the Talangsari case. Finally, at the end of December 1998, President Habibie issued a presidential decree (No.101/1999) granting clemency to fifteen prisoners. After the release from Nusakambangan prison, they came straight to Jakarta to meet Hendropriyono and other political prisoners and declared the signing of the islah agreement in Muhajirin Mosque inside the Ministry of Transmigration complex. In the welcoming speech, Hendropriyono said that these prisoners were jailed for political activities that were in differences with the government. He said:

They were not criminals, thiefs and robbers. They were jailed because of politics and thus there was a misunderstanding with the government regarding policy. ${ }^{10}$

${ }^{8}$ See, Widjiono, Geger Talangsari, especially chapter sixteen and seventeen.

9 Ibid, p. 241.

${ }^{10}$ As quoted in Widjiono, p. 246. 
At this occasion he promised that he would help with the release of other Islamic political prisoners jailed during the Suharto's authoritarian period.

Despite some representatives of the victims signing the islah agreement, the Talangsari case continued to attract public attention. Delegation after delegation visited the provincial parliament in the capital city of Bandar Lampung, each presenting their views on the case. Basically, the victims were divided almost equally between the supporters of the islah agreement and those who preferred alegal solution. The first camp received political support from the local parliament in Sukanda district (East Lampung) which issued an official statement dated 13 December 2000, endorsing the non-legal solution through the islah agreement and at the same time urging the parties not to reopen the case for the sake of improving the welfare of the people in East Lampung district ${ }^{11}$ Meanwhile, the latter camp supported the organizations like Kontras, Smalam and the Legal Aid Foundation-Lampung branch, in arguing that the government should deal with this case through legal means. As in the case of Tanjung Priok, this took place at the time when the Parliament had just enacted the Law on Human Rights Court (no.29/2000), opening up the possibility of dealing with the Talasangsari killings through a special human rights court.

2001 saw a slight increase in public gatherings organized by various parties from both sides, either in support of the islah agreement or of legal means. This time both sides lobbied the National Commission on Human Rights proposing their different views on the case. One idea that was proposed by the human rights organizations was to establish a Commission to Investigate the Human Rights Violations in Talangsari (Komisi Penyelidikan Pelanggaran Hak Asasi Manusia untuk Talangsari, KPP Ham Talangsari). But both the government and the National Commission on Human Rights refused to do this. However, by mid-2001 there was speculation that the National Commission was preparing a special team to investigate the Talangsari case, to be headed by Koesparmono Irsan, a former high-ranking police officer, although the details of tasks and of the members of the team remained unclear. ${ }^{12}$ Up to September 2001, the Indonesian public was still

11 Ibid, pp. 236-239.

12 "Komnas HAM Setuju Usut Kasus Talangsari Lampung, Republika Online, 25 July 2001, http://www.republika.co.id/berita/koran/2001/07/25/37538.shtm 
wondering whether the team had done the necessary works needed to establish the KPP Ham Talangsari. On 6 September 2001 Kontras led a delegation including 28 victims of the Talangsari case to the National Commission on Human Rights demanding the establishment of the KPP Ham Talangsari.13 In response, BN Marbun from the National Commission explained the difficulty of investigating the case because "certain parties had threated, pressured and imposed obstacles" to the National Commission not to go ahead with the investigation of the Talangsari case. ${ }^{14}$

As the debates on this case continued, there are interesting political developments regarding to the Talangsari case that need attention here. First, there was division even among those who supported the islah agreement. The division was caused mainly by fighting over the distribution of material compensation given by Hendropriyono and also by personal rivalry ${ }^{15}$ This gave the impression to the public that there were different motives for the parties signing the islah agreement. Second, in between October and November 2001, Kontras (on behalf of five organizations) and the representatives of some of the victims came to the Administrative Court in Jakarta to submita legal action against the Megawati government for appointing Hendropriyono as the new head of the Bureau of National Intelligence. ${ }^{16}$ The legal base for this action was that the government ignored the principle of good governance (among others) by appointing him before his name was cleared of implicated in the Talangsari killings. ${ }^{17}$ These complex political developments have made the efforts to deal the Talangsari case through legal means even harder, due to the lack of consensus

13 “Komnas HAM Didesak Bentuk KPP HAM Kasus Lampung”, Republika Online, 7 September 2001, http://www.republika.co.id/berita/koran/2001/09/07/43452.shtm

14 "Komnas HAM Akui Ditekan dan Diancam", Republika Online, 7 September 2001, http://www.republika.co.id/berita/online/2001/09/07/43559.shtm

15 Refer to the rivalry between the Fauzi Isnan group and the Sudarsono group. See, Widjiono, Geger Talangsari, p. 230.

${ }^{16}$ Hendropriyono was appointed for the job in August 2001."Korban Talangsari Lampung Gugat Presiden Megawati", Republika Online, http://www.republika.co.id/berita/koran/2001/11/ $\underline{10 / 51676 . s h t m}$

17"Kontras Akan Gugat Hendropriyono”, Republika Online, http://www.republika.co.id/ berita/online/2001/10/23/48702.shtm; and "Pengangkatan Hendro sebagi Kepala BIN Digugat", Republika Online, http://www.republika.co.id/berita/online/2001/11/09/51717.shtm 
among the victims about how to resolve the case and, on top of that, the appointment of Hendropriyono to this powerful intelligence body. 18

Third, after one and a half years, the National Commission on Human Rights had failed to come up with concrete steps to deal with this case. This all, unfortunately, happened at the time when the National Commission underwent a change in leadership in 2002. Many unfinished matters (including the Talangsari case) had to be handed over from the chairmainship of Djoko Soegianto to that of Abdul Hakim Garuda Nusantara. This supported the accusations coming from some human rights organizations about the ineffectiveness of the National Commission to undertake such a big task ${ }^{19}$ Up till now, despite the fact that the National Commission has promised to reinvestigate the case, it still has not decided on options that need to be adopted to deal with the Talangsari case. ${ }^{20}$

In sum, following the fall of Suharto in 1998, public pressure to deal with the Talangsari killings in 1989 increased. The changing balance of power during the Habibie period and subsequently the Wahid period, created a division between those who opted to deal with the Talangsari case through an islah agreement and those who opposed the agreement in favor of legal means. Both sides have contested the issue ever since, which to a certain extent has contributed to the uncertainty about which mechanism that should properly be adopted to deal with the Talangsari case. Unfortunately, pressures from the human rights organizations had not moved the National Commission on Human Rights to establish a KPP Ham Talangsari, posing many questions about the commitment of the Commission to deal with the case and, more importantly, about whether Indonesia has the political will to resolve this case once and for all.

\section{B. Reflections from the Indonesian experience}

The Indonesian experience tells us that dealing with past abuses is a political process involving intense and constant political struggles among various parties.

18 "KPP HAM Trisakti Terhambat”, Republika Online, 11 January 2002, http://www.republika. co.id/berita/koran/2002/01/11/59869.shtm; and "PTUN Terima Intervensi Kepala BIN",Republika Online, 1 February 2002, http://www.republika.co.id/berita/koran/2002/02/01/62857.shtm

19 "Komnas HAM Diminta Tuntaskan Kasus Talangsari”, Republika Online, 5 February 2003, http://www.republika.co.id/berita/koran/2003/02/05/112998.shtm.

20 Warga Talangsari Kembali Datangi Komnas HAM", Kompas Online, http://www.kompas.com/ kompas- cetak/0302/05/nasional/114887.htm.

JURNAL THEOLOGIA — Volume 32, No. 1, Juni 2021 
As shown earlier, in many of the past human rights abuses the former President Suharto and also other high-ranking military officers are implicated and this has created an atmosphere of both denial and anxiety among them. They have deliberately showed various forms and means of resisting and opposing any attempts to investigate or to prosecute the perpetrators of the past human rights abuses. This article offers the case of how post- Suharto Indonesian has begun to address the Talangsari killings of 1986 . It has pointed out that public pressure to reinvestigate the case increased a great deal after the fall of Suharto in 1998. The changing balance of power during the Habibie and the Wahid presidencies opened up room for a coalition of the victims, human right organizations, politicians, and lawyers to put pressure on the government to deal with the Talangsari case through prosecution or trials. It has also shown that both secular and Islamic constituents in Indonesia were important forces behind this pressure, which is different from the East Timor case. As a result, the case has recently been brought to trial. The complexity of this story is, as it has been discussed earlier, that retired General Hendropriyono and some representatives of the victims signed islah (peace) agreements as a way to deal the case through a non-legal mechanism.

What does the Talangsari killings case tell us? There are two main issues to raise here. First, the case study brings us back to the debates about the relative benefits of retributive justice and restorative justice in modern society. The first refers to a process through which justice can be achieved by prosecuting the perpetrators for their past crimes, the benefit being that this upholds the rule of law, and the dignity of the victims and it also breaks the cycle of impunity. The latter refers to a process through which all parties (perpetrators, victims and the community at large) are involved in enhancing the reconciliation process and in restoring moral order. Both processes have strengths and weaknesses. In this respect, the case of the Talangsari killings as it have unfolded thus far highlight the complexity of dealing with past human rights abuses in post-Suharto Indonesia.

Second, critical analysis of the phenomenon of islah is needed. In other words, in debating about the merits and demerits of islah agreements many questions have been raised: Do islah agreements belong to the religious realm or the legal realm? Are they legally binding? Do they focus primarily on forgiving each other without public disclosure? Do they lead to ways to uncover the truth of the past? Whose truth: the perpetrators or the victims? The list of questions 
could be extended. As this idea came from former high-ranking military officers, therefore the need to scrutinise the motives behind it is relevant. In other word, the role of islah agreements in enhancing or in obstructing the reconciliation process in post-Suharto Indonesia has yet to be critically examined.

\section{The Southeast Asian Comparison: Thailand, Philippines, Cambodia and Burma}

\section{Thailand: Silence about the past}

In Thailand two important events have been the subject of public attention: the 6 October 1976 massacre in Thammasat University and the killings that happened during the May 1992 uprising in Bangkok. The 6 October 1976 massacre is an event that is still full of mystery, with many unanswered questions regarding how people were actually injured, killed, disappeared and how to bring about justice to the victims (many of them were students). Conflicting views emerged immediately about the circumstances that led to the killings. ${ }^{21}$ Thongchai Winichakul, a witness and a historian, argues that even until recently Thai society has remained ambivalent and silent about this event and he writes that "the memories of the massacre are still contested, unsettled and disturbing" and therefore it would take a long time for everyone including the Thai government to know the truth about this painful chapter of the past. ${ }^{22}$ No efforts are being made to reinvestigate the case as everyone including the victims and perpetrators have their own memories about this event. The complex nature of the political conflict and of the political players in Thailand at this point in time makes it difficult to find the truth. The 6 October 1976 massacre occurred during a brief democratic period (1973-1976), which was marked by intense power struggles between the political elites and the military. Students from Thammasat University had to pay dearly for their idealism and political activism as the politics of the Cold war and the rising of anti-communism sentiment worsened the

21 As suggested in Thongchai Winichakul, "Remembering/Silencing the Traumatic Past, the Ambivalent Memories of the October 1976 Massacre in Bangkok" in Shigeharu Tanabe and Charles F. Keyes (eds) Cultural Crisis and Social Memory, Modernity and Identity in Thailand and Laos (Honolulu: University of Hawaii Press, 2002), pp. 243-283.

22 P. 277. 
divisions that were already present in Thailand. ${ }^{23}$ Meanwhile, the May 1992 killings happened as a result of mass protests against the appointment of General Suchinda Kaprayoon as a new prime minister. This was a more a clear cut case. ${ }^{24}$ Suchinda and his military cohorts had the power to give orders to shoot protesters in streets of Bangkok and therefore they can be categorized as the perpetrators. Of course, no one has brought to court because before he resigned, Suchinda declared an amnesty for himself and other military officers and therefore they could not be subject to future investigation. ${ }^{25}$

The Thailand experience illustrates the difficulty of dealing with the past human rights abuses as the Thai society has been silent and ambivalent about the two past events. Finding the truth is still a long way off. Perhaps the commemoration activities occurred in 1996 to remember the 6 October 1976 massacre, and perhaps this can be seen as the first step towards a long journey to uncover the truth about this event. Many obstacles remain as military leaders and political leaders may have reservations about reinvestigating this event because of the likelihood that it would rock the balance of power in Thailand and open up 'old' wounds in Thai society.

\section{The Philippines: Forgiving the past}

There has been a tendency in the Phillippines to embrace what is known as 'forgiving the past' as until today no one has been put on trial for committing human rights abuses. The fall of the Marcos regime opened up a political space and also paved the ways to the restoration of civil liberties. ${ }^{26}$ The then President

23 On the Thai studentactivism, see Elinor Bartak, The Student Movement in Thailand, 1970-1976, Working Paper 82 (Clayton, Centre of Southeast Asian Studies, Monash University, 1993).

24 Chaiwat Satha-Anand, "Imagery in the 1992 Nonviolent Uprising in Thailand" in Stephen Zunes, Lester

R. Kurtz and Sarah Beth Asher (eds) Nonviolent Social Movements, A Geographical Perspective (Malden, Mass., USA and Oxford, UK, 1999), pp. 158-173.

25 David Murray, Angels and Devils, Thai Politics from February 1991 to September 1992-AStruggle for Democracy? (Bangkok: White Orchid Press, 1996), pp. 175-176.

26 For various views on this political transition, see See Benedict J. Kerkvliet and Resil B. Mojares (eds) From Marcos to Aquino, Local Perspectives on Political Transition in the Philippines (Manila: Ateneo de Manila University Press, 1991; and also David G. Timberman, A Changeless Land: Continuity and Change in the Philippines (New York: M.E. Sharpe, 1991). 
Corazon Aquino faced the mounting pressure from human rights organizations, church-based organizations, and also non- government organizations (NGOs) to deal with the human rights abuses that occurred during the Marcos era. Most of the abuses happened during the martial law period which lasted more than a decade (from 1972 to the early 1980s) and a range of people were affected, including students, workers, farmers, lawyers and civilian politicians. ${ }^{27}$ In the early days of Aquino's presidency, there were efforts to bring about justice by putting military leaders on trial (including the trial of Benigno Aquino killers in August 1983). These had the support of the general public who had a strong conviction about the commitment of the Aquino government to prosecute the perpetrators of the past human rights abuses.

However, as power struggles among political elites, the military and nonstate actors destabilised almost the entire period of Aquino's presidency, the efforts to find strategies to deal with the past abuses lost momentum. No perpetrators were brought to court at this point. The election of Fidel Ramos, a former general who defected from Marcos during the heyday of the "people's power" movement in 1986, made the likelihood of any serious attempt to bring justice to the victims of abuse and their relatives even more remote. It is debatable as to whether the powerful Catholic Church and its tradition of forgiving has influenced the capacity of Filipinos to forgive what has happened in the past. In a comparative sense, the democratisation processes that occurred during postMarcos period was welcomed and monitored closely by the neighboring countries. However, the failure to deal with the past abuses in the Philippines tells the region that opening up the painful past is never easy because, as in the case of Thailand, it can threaten the balance of power.

\section{Cambodia: Struggles to deal with the past}

Cambodia has been through difficult stages in its national building efforts: the dismantling of colonial power, the experience of civil war, authoritarian regime, the effects of the Cold war, until recently, the establishment of democracy. Efforts to find strategies to deal with the past in Cambodia have been overshadowed by ongoing power struggles between domestic and international

\footnotetext{
27 Benedict Anderson, "Cacique Democracy in the Philippines" in The Spectre of Comparisons, Nationalism, Southeast Asia and the World (London and New York: Verso, 1998), pp. 192-226.
}

JURNAL THEOLOGIA — Volume 32, No. 1, Juni 2021 
political players. ${ }^{28}$ Until today only a few from the leadership of the Khmer Rouge regime (led by Pol Pot) been brought to court. It is estimated that about 1-2 million people died during the Khmer Rouge period (1975-1979), regarded by some as a period of genocide in modern Cambodia history. ${ }^{29}$

In 1997, both new Cambodian leaders Hun Sen and Prince Norodom Ranariddh asked the United Nations (UN) to assist Cambodia to establish a tribunal to try the Khmer Rouge leaders, similar to the ad hoc tribunals in the former Yugoslavia and in Rwanda. ${ }^{30}$ The UN responded by forming a Group of Experts to prepare to establish a tribunal in Cambodia. The UN prepared a set of recommendations for an international tribunal in 1998, however Hun Sen changed his mind about the issues. He argued for upholding the principles of 'national sovereignty', preferring to have a Cambodian court to try the Khmer Rouge leaders. At the international level, a few members of the Security Council also disagreed with the idea of establishing an international tribunal in Cambodia. Not many years earlier, even until in the early 1990s, the 'big powers' such as the US, China, and some European countries had formed an international coalition against Vietnam's puppet government (led by Hun Sen) in Cambodia, and ironically the Khmer Rouge was part of the coalition. Consequently, the establishment of an international tribunal would uncover not only the truth about what happened during the Khmer Rouge period but also the role of the big players' in the international coalition that operated along the Thai- Cambodian border during the 1980s and the 1990s. ${ }^{31}$

As the struggle continued, in 2001, the National Parliament and Senate passed the "Law on the Establishment of the Extraordinary Chambers in the

\footnotetext{
${ }^{28}$ Debates on the nature of Cambodia's democratic transition, see Sorpong Peou, Intervention and Change in Cambodia, Towards Democracy? (Bangkok and Singapore: Silkworm Books and Institute of Southeast Asian Studies, 2000); and David W. Roberts, Political Transition in Cambodia 1991-99, Power, Elitism and Democracy (Richmond: Curzon Press, 2001).

${ }^{29}$ On the Khmer Rouge period, see Ben Kiernan, The Pol Pot Regime, $2^{\text {nd }}$ edition, (New Haven and London: Yale University Press, 2002) and David Chandler, Brother Number One, A Political Biography of Pol Pot (Boulder: Westview Press, 1999).

30 Unless mentioned otherwise, the following accounts will be based from Nayan Chanda, "Cambodia: Unable to Confront the Past" in Yoichi Funabashi (ed) Reconciliation in the Asia-Pacific (Washington D.C.: United States Institute of Peace Press, 2003), pp. 111-132.

${ }^{31}$ Chanda, p. 116.
} 
Courts of Cambodia for the Prosecution of Crimes Committed during the Period of Democratic Kampuchea". As stated in the law, a tribunal would be established in the Courts of Cambodia with participation from the international community. ${ }^{32}$ However, the idea of having the majority of Cambodian judges in the proposed tribunal caused public criticism domestically and internationally. For this and other reasons, in early 2002, the UN Office of Legal Affairs (OLA) withdrew its negotiation with the Cambodian government, creating uncertainty regarding the future of the tribunal..$^{33}$ In addition, only a few judges have law degrees and most are yet to familiarize themselves with the international laws dealing with genocide and crimes against humanity. ${ }^{34}$ It must be noted here that the establishment of a tribunal in Cambodia with or without international support is crucial as a first step to deal with the human rights abuses that occurred during the Khmer Rouge period. However, like other countries emerging from civil wars, Cambodia also has other urgent priorities in developing the economy, maintaining political stability and job creation. The efforts to find justice and reconciliation must go along with the above priorities. ${ }^{35}$

\section{Burma: Ignoring the past}

In the case of Myanmar, the event that is often brought to both domestic and international attention is the killings that occurred during the period of the democratic movement in 1988. Between the 8 August 1988 (known as "8-8-88") and the 18 September 1988 when the Burmese military launched a coup, it is estimated that thousands students and civilians were killed and murdered in the streets of Rangoon and other cities throughout Burma. ${ }^{36}$ To this point, no public

\footnotetext{
32 Helen Jarvis, "Trials and Tribulations, The Latest Twists in the Long Quest for Justice for the Cambodian Genocide", Critical Asian Studies, Vol. 34, Nop. 4, 2002, p. 609.

${ }^{33}$ Chanda, p. 123 and Jarvis, p. 610.

${ }^{34}$ Chanda, p. 119.

${ }^{35}$ As suggested in a report prepared by Center for Social Development, The Khmer Rouge and National Reconciliation-Opinions from the Cambodians (Phnom Penh: Center for Social Development, 2001).

36 On the origins of the 8 August 1988 Uprising, see Bertil Lintner, Outrage, Burma's Struggle for Democracy (London and Bangkok: White Lotus, 1990) and on author's own study, Priyambudi Sulistiyanto, Burma: The Politics of Uncertain Transition, 1988-1994, MA thesis (Adelaide: Flinders University, 1995).
} 
inquiry has been established to investigate this event. Since the military generals (then SLORC and the State Peace and Development Council, SPDC, respevtively) which ordered the killings are still linked with powerful institutions, to deal with the past human rights abuses impossible.

The difficulty might be the fear and anxiety of the military leaders surrounding the potential investigation of their human rights records. Burmese military leaders would likely work very hard to resist or oppose any attempts to investigate or to prosecute military personnel for their roles in the past human rights abuses. The Burmese military leaders may insist that the tatmadaw is a respected institution and the military officers are honorable people who have contributed much to the country. Prosecuting military officers could destroy their image and honor in the eyes of the people and therefore they may not hesitate to go to great lengths (a military coup or a military show of force, intimidation) in order to stop the investigations taking place.

Currently Myanmar is facing multi-dimensional challenges, like improving the economic situation which has been in bad shape for a quite a while, maintaining political stability both in the centre and in the regions, improving public infrastructure, and upholding the rule of law. In other words, even in a democratic Myanmar the issues related to dealing with the past human rights abuses might not seem as urgent as other issues. In this kind of situation, the Myanmar democratic leaders may prefer a safe strategy which to address the urgent issues affecting the general population and avoid addressing the human rights issues that mightendanger the balance of power in Burma. In addition, legal constraints are facing Myanmar. The judiciary in Myanmar is not an independent body like that in a democratic country. In Myanmar, and those who occupy top positions in the Supreme Court and the Attorney General were influenced by the military powerful circles. ${ }^{37}$ The existing Myanmar legal system would be limited in its ability to deal with the complexities of human rights cases and consequently it would need to be reformed by incorporating new legal instruments, conventions, and ideas available at the international level. The willingness of the Myanmar people themselves to deal with their own past is also important factor

37 Tin Maung Maung Than, "Myanmar, Military in Charge" in John Funston (ed) Government and Politics in Southeast Asia (Singapore: Institute of Southeast Asian Studies, 2001), pp. 227-228. 
in this respect. It is acknowledged that the history of Myanmar is a history of repression, suffering, and conflict and consequently the people have suffered greatly. ${ }^{38}$ This has affected different sections of the society, from those in the cities to those who live in the hills and along the borders. In other words, everyone has shared a traumatic situation caused by the decades of political conflict and civil war.

\section{Conclution}

This article has examined the politics of reconciliation in post-Suharto Indonesia with a Southeast Asian regional comparison. As was suggested earlier, the difficulties experienced by Indonesian are not unusual as many new democracies have experienced similar situations. The three main strategies that have been adopted by new democracies are trials, amnesties, and truth commissions. Each of these strategies has its advantages and disadvantages. As was pointed out earlier, since the 1980s and 1990s truth commissions have been an increasingly popular mechanism for dealing with past abuses among new democracies. The appeal of a truth commission lies in the belief that it can strengthen the reconciliation process by giving an opportunity for both the victims and the perpetrators to exchange accounts of the past abuses in a series of public hearings. Indonesia is currently preparing to establish a truth and reconciliation commission to deal with the past human rights abuses. ${ }^{39}$

However, considering the fact that Indonesia has established a mechanism for the prosecutiom of perpetrators through trials, and used it for the East Timor and the Tanjung Priok cases, it remains to be seen whether it restores a sense of justice to the victims. Perhaps we need to go beyond the political and legal world to find ways of dealing with the past. Here, it has been suggested that there are no "simple" solutions for Indonesia and Southeast Asia to deal with past human rights abuses. The Indonesian case and the experiences from the Southeast Asian region tell us that dealing with the past is a deeply political process involving

\footnotetext{
38 Christina Fink, Living Silence, Burma under Military Rule (Bangkok and London: White Lotus and Zed Books, 2001).

${ }^{39}$ Communication with Ifdhal Kasim, Executive Director, ELSAM (15/5/04); and also see "RUU KKR di Tengah Tarikan Kepentingan”, Kompas, 26 May 2004.
} 
intense and constant political struggles among the elites and various parties within civil society.

It is argued here that reconciliation is absolutely crucial and desperately needed. Reconciliation can be seen as a willingness on behalf of the victims not to seek revenge and a willingness to forgive the perpetrators unconditionally, even in a situation where the perpetrators remain stubborn or arrogant. Reconciliation is the victim's prerogative and no one can act on his/her behalf, including the state or government. Reconciliation can complement forgiveness in the sense that it helps to heal the unfinished business in the past and to move things forward in terms of building a new kind of human relationship. As in Minow's words (2001:14) 'the act of forgiving can reconnect the offender and the victims and establish or renew a relationship'. ${ }^{40}$ It is hard but not unachievable, nonetheless. Support for forgiveness can be drawn from religious traditions and cultural and secular sources. In Indonesia, Thailand, the Philippines, Cambodia, and Burma there are similar traditional celebrations each year which focus on forgiving each other's mistakes. For instance, in Indonesia there is idul fitri at the end of Ramadhan (for Muslims), there are the Easter celebrations (for Christians), loy kratong for Thai Buddhists. or on New Year day. A Burmese scholar has proposed that the water festival thingyan that happens annually in the month of April could be used as focal point for a ceremony of national reconciliation in Burma. ${ }^{41}$ Cambodia also has its own version of this "water festival". I believe that there are many forms of the locally-based reconcilitiaton and forgiveness ceremonies practiced throughout the Southeast Asian region, and that within these traditions lies a great deal of potential for encouraging reconciliation and forgiveness among the people of this region.

40 Minow, Between Vengeance and Forgiveness: Facing History after Genocide and Mass Violence

(Boston: Beacon Press, 1998), p. 14.

41 Kanbawza Win, Impunity Inconceivable, Working Paper, 01/02 (Washington D.C.: Technical Advisory Network Burma, 2002), pp. 18-19. 


\section{References}

Al Chaidar, Lampung Bersimbah Darah (Jakarta: Madani Press, 2000).

Anderson, Benedict, "Cacique Democracy in the Philippines" in The Spectre of Comparisons, Nationalism, Southeast Asia and the World (London and New York: Verson, 1998)

Auguilar, Paloma, "Justice, Politics, and Memory in the Spanish Transition" in Alexandra Barahona de Brito, Carmen Gonzalez-Enrique, and Paloma Aquilar (eds) The Politics of Memory, Transitional Justice in Democratizing Societies (Oxford: Oxford University Press, 2001)

Bartak, Elinor, The Student Movement in Thailand, 1970-1976, Working Paper 82 (Clayton, Centre of Southeast Asian Studies, Monash University, 1993).

Barton, Greg, Gus Dur, The Authorized Biography of Abdurrahman Wahid (Jakarta and Singapore: Equinox Publishing, 2002).

Bronkhorst, Daan, Truth and Reconciliation, Obstacles and Opportunities for Human Rights (Amsterdam: Amnesty International Dutch Section, 1995).

Budiman, Arief, "The 1998 Crisis: Change and Continuity" in Arief Budiman, Barbara Hatley and Damien Kingsbury (eds) Reformasi: Crisis and Change in Indonesia (Clayton: Monash Asia Institute, Monash University, 1999)

Center for Social Development, The Khmer Rouge and National ReconciliationOpinions from the Cambodians (Phnom Penh: Center for Social Development, 2001).

Chaiwat Satha-Anand, "Imagery in the 1992 Nonviolent Uprising in Thailand" in Stephen Zunes, Lester R. Kurtz and Sarah Beth Asher (eds) Nonviolent Social Movements, A Geographical Perspective (Maden, Mass., USA and Oxford, UK, 1999)

Chanda, Nayan, "Cambodia: Unable to Confront the Past" in Yoichi Funabashi (ed) Reconciliation in the Asia-Pacific (Washington D.C.: United States Institute of Peace Press, 2003)

Chandler, David, Brother Number One, A Political Biography of Pol Pot (Boulder: Westview Press, 1999). 
Crocker, D.A., "Truth Commissions, Transitional Justice, and Civil Society" in Robert I. Rotberg and Dennis Thompson (eds) Truth v.Justice, The Morality of Truth Commissions (Princeton and Oxford: Princeton University Press, 2000)

Elsam, Laporan Hak Asasi Manusia 2003, a report (Jakarta: Elsam, 2003).

Fink, Christina, Living Silence, Burma under Military Rule (Bangkok and London: White Lotus and Zed Books, 2001).

Gorjao, P., "An Indonesian Truth and Reconciliation Commission? The South African Experience" in Inggrid Wessel and Georgia Wimhofer (eds) Violence in Indonesia (Hamburg: Abera Publishing House, 2001).

Fink, Christina, Living Silence, Burma under Military Rule (Bangkok and London: White Lotus and Zed Books, 2001).

Funabashi, Yoichi (ed) Reconciliation in the Asia-Pacific (Washington D.C.: United States Institute of Peace Press, 2003).

Hayner, Priscilla, Unspeakable Truths, Confronting State Terror and Atrocity (New York and London: Routledge, 2001).

Huyse, L., "Dealing with the Past and Imaging the Future" in Luc Reychler and Thania Paffenholz (eds) Peace Building. A Field Guide (Boulder and London: Lynne Reinner Publishers, 2001).

International Crisis Group, Indonesia: Impunity versus Accountability for Gross Human Rights Violations, Report No. 12 (Jakarta and Brussels: ICG, 2001).

Jarvis, Helen, "Trials and Tribulations, The Latest Twists in the Long Quest for Justice for the Cambodian Genocide", Critical Asian Studies, Vol. 34, No. 4, 2002.

Kanbawza Win, Impunity Inconceivable, Working Paper, 01/02 (Washington D.C.: Technical Advisory Network Burma, 2002).

Kerkvliet, Benedict J. and Resil B. Mojares (eds) From Marcos to Aquino, Local Perspectives on Political Transition in the Philippines (Manila: Ateneo de Manila University Press, 1991).

Kiernan, Ben, The Pol Pot Regime, $2^{\text {nd }}$ edition (New Haven and London: Yale University Press, 2002). 
Kirtz, Neil J. (ed) Transitional Justice (Washington D.C.: United States Institute of Peace Studies, 1995).

Komisi Nasional Hak Asasi Manusia, Keadilan Dalam Masa Transisi (Jakarta: KomnasHam, 2001).

Lintner, Bertil, Outrage, Burma's Struggle for Democracy (London and Bangkok: White Lotus, 1990).

McAdams, A. J. (ed) Transitional Justice and the Rule of Law in Mew Democracies (Notre Dame and London: University of Notre Dame Press, 1997).

Minow, Martha, Between Vengeance and Forgiveness: Facing History after Genocide and Mass Violence (Boston: Beacon Press, 1998)

Murray, David, Angels and Devils, Thai Politics from February 1991 to September 1992-A Struggle for Democracy? (Bangkok: White Orchid Press, 1996).

Neir, Aryeh, "Rethinking Truth, Justice, and Guilt after Bosnia and Rwanda" in Carla Hesse and Robert Post (eds) Human Rights in Political Transitions: Gettyburg to Bosnia (New York: Zone Books, 1999)

Osiel, M., "Making Public Memory, Publicly" in Carla Hesse and Robert Post (eds) Human Rights in Political Transitions: Gettyburg to Bosnia (New York: Zone Books, 1999)

Rigby, Andrew, Justice and Reconciliation After the Violence (Boulder and London: Lynne Reinner Publishers, 2001).

Roberts, David W., Political Transition in Cambodia 1991-99, Power, Elitism and Democracy (Richmond: Curzon Press, 2001).

Robertson, G. Crimes Against Humanity (New York: The New Press, 1999).

Roht-Arriaza, Naomi, "The Role of International Actors in National Accountability Processes" in Alexandra Barahona de Brito, Carmen Gonzalez-Enriquez, and Paloma Aquilar (eds) The Politics of Memory, Transitional Justice in Democratizing Societies (Oxford and New York: Oxford University Press, 2001)

Rotberg, Robert I. and David Thompson (eds) Truth v. Justice, The Memory of Truth Commissions (Princeton and Oxford: Princeton University Press, 2000).

Rudolp, Christopher, "Constructing an Atrocities Regime: The Politics of War Crimes Tribunals", International Organisation, Vol. 55, No. 3, 2001 
Sorpong Peou, Intervention and Change in Cambodia, Towards Democracy? (Bangkokand Singapore: Silkworm Books and Institute of Southeast Asian Studies, 2000).

Sulistiyanto, Priyambudi, Burma: The Politics of Uncertain Transition, 1988-1994, MA thesis (Adelaide: Flinders University, 1995).

Sulistiyanto, Priyambudi, "Politics of Justice and Reconciliation in post Suharto Indonesia", Journal of Contemporary Asia, 37, 1, 2007

Syukur, Abdul, Gerakan Usroh Di Indonesia, Peristiwa Lampung 1989 (Yogyakarta: Ombak, 2003).

Thongchai Winichakul, "Remembering/Silencing the Traumatic Past, the Ambivalent Memories of the October 1976 Massacre in Bangkok" in Shigeharu Tanabe and Charles

F. Keyes (eds) Cultural Crisis and Social Memory, Modernity and Identity in Thailand and Laos (Honolulu: University of Hawaii Press, 2002)

Timberman, David G., A Changeless Land: Continuity and Change in the Philippines (New York: M.E. Sharpe, 1991).

Tin Maung Maung Than, "Myanmar, Military in Charge" in John Funston (ed) Governmentand Politics in Southeast Asia (Singapore: Institute of Southeast Asian Studies, 2001).

Wasis, Widjiono, Geger Talangsari (Jakarta: Balai Pustaka, 2001).

Witoelar, Wimar, No Regrets (Jakarta and Singapore: Equinox Publishing, 2002).

Newpapers (printed and online):

Kompas Merdeka

Kompas online (www.kompas.com) Republika online (www.republika.co.id) 